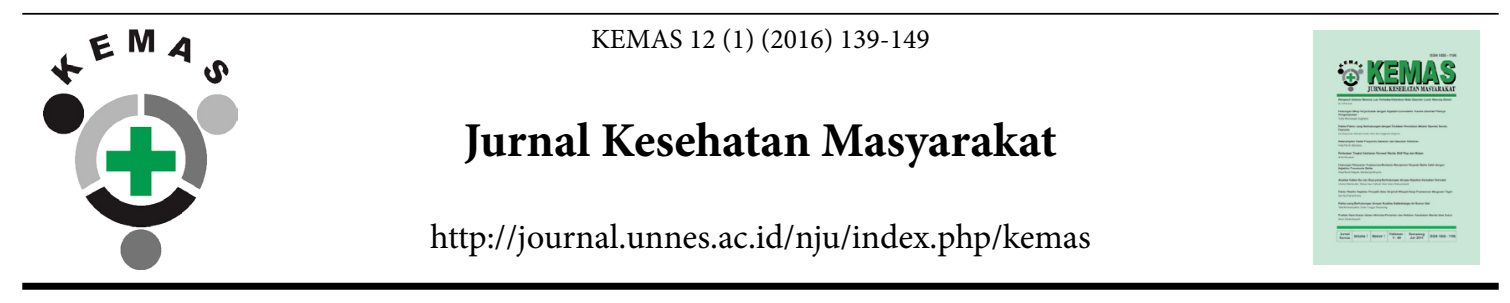

\title{
THE DETERMINANTS OF INFANT MORTALITY IN NEONATAL PERIOD
}

\author{
Indah Purnama Sari ${ }^{\bowtie}$, Yustini Ardillah, Try Any Widyastuti \\ Public Health Faculty, Sriwijaya University
}

\section{Article Info \\ Article History: \\ Submited January 2016 \\ Accepted June 2016 \\ Published July 2016 \\ Keywords: \\ Mortality; Neonatal; Ris \\ DOI \\ http://dx.doi.org/10.15294/ \\ kemas.v12i1.4882}

\begin{abstract}
Neonatal mortality is mortality happening to newborn baby who are alive during the birth but died after first month of life (28 days after being delivered). This study used data from 2013 reports. The aim of this study was to identify determinants of neonatal mortality risk. Case control design was used. Population of cases were newborn baabybies who dying within 28 days after the birth, while the population of controls were newborn baby who do not die within 28 days, selected from the same population of cases. Cases and controls proportion were 1:3 with 39 babies served as cases and 117 babies as controls. Cases were identified form The Health Office and PHC reports, meanwhile controls were selected from neighbor of cases. Univariate, bivariate and multivariate analysis were conducted in this study. The results shows that newborn weight $(p=0,03)$, immediately breastfeeding $(\mathrm{p}=0,00)$ and postnatal care $(\mathrm{p}=0,00)$ are the risk factors for neonatal mortality.
\end{abstract}

\section{Introduction}

The infant mortality rate is one indicator which determines the health status of children. Neonatal period is a crucial period in the growth and development of babies. More than four million babies die in neonatal period (the first four weeks of birth) from 130 million babies born every year (Titaley, 2008). Neonatal deaths occur in countries around the world. Indonesia (35.3\%) is ranked second from the bottom, slightly above the Philippines (34.2\%) in the neonatal mortality rate during 1990 to 2010 (Rajaratnam, 2010). The infant mortality rate (IMR) in Indonesia has yet to reach the targeted results based on Millennium Development Goal's (MDG), goal 4 which is to reduce infant mortality (IMR) by two-thirds between 1990 and 2015, 23 per 1,000 live births. Based on the results of Indonesia Demographic and Health Survey (IDHS) in 2012, it shows that the infant mortality rate (IMR) in Indonesia is amounted to 32 per 1000 live births with no change in neonatal mortality rate (NMR) (19 per 1,000 live births) (IDHS 2007 and IDHS 2012) (BPS, BKKBN, Kementrian Kesehatan, 2013).

The attention for several efforts to reduce neonatal mortality rate (NMR) (0-28 days) is important because neonatal mortality contributes to $56 \%$ of the total baby mortality. The major cause of death problems in infants and toddlers are in the neonatal period (newborn infants aged 0-28 days). Complications become the main cause of death such as asphyxia, low birth weight and infection (Kemenkes RI, 2013). In addition to the causes of death that have been mentioned, there are several other factors that can cause neonatal mortality such as factors of fetus/infant, maternal/ mothers, health care, and socio-demography of mother. Mosley and Chen (2003) formulate the proximate determinants or intermediate variables that directly affect the risk of illness (morbidity) and death (mortality) of children. Proximate determinants are grouped into five

\footnotetext{
Correspondece Address: 
categories, among others: maternal factors (age, parity, birth spacing), contaminated environment (air, food/water, the skin/soil, insect vectors), malnutrition (calories, protein, vitamins and minerals), injuries (accidents) and health services (prevention and treatment).

Various studies have been conducted, among others is by Titaley (2008) which states that birth weight is a strong predictor of mortality risk where the infants with low birth weight ( $<2500$ grams) have the possibility of 5.5 times higher for neonatal mortality as compared with infants with normal birth weight (25003500 grams) (95\% CI: 3.59 to $8.57, \mathrm{p}=0.00$ ). Results of research from Bashir (2013) find that there is a relationship between the mother's age at delivery, maternal parity, level of household welfare (social and economic), gender of the baby, type of birth, complications of pregnancy and childbirth complications. Research conducted in northern Ghana also shows that maternal age and number of children (parity) are associated with neonatal mortality (Welaga, 2013). Research by Upadhyay, et al. (2011) also shows that babies born to mothers aged $<20$ years old have 2 times higher risk of neonatal death as compared with infants born to mothers aged 25-29 years old (95\% CI: 1.22 to 3.21 ).

Health service factors also play a role in neonatal mortality. These factors include antenatal care (ANC), birth attendants, place of birth, type of birth, breast-feeding (IMD) and the postnatal visit. Debelew research (2014) shows that women with $\geq 4$ times of ANC visit frequency have 0.35 times lower risk for neonatal mortality than women who never do ANC visit (95\% CI: 0.18 to 0.68 ). The same study also finds that mothers who deliver the baby in health facilities have 0.43 times lower risk for neonatal mortality than women who deliver the baby at home (non-health facilities) ( $95 \%$ CI: 0.17 to 0.99 ). A research by Edmond, et al. (2006) also shows that the longer the delay in giving breastfeeding, the greater the risk of the baby in experiencing neonatal mortality (delayed breastfeeding).

Various studies have been conducted to determine the risk factors for neonatal mortality in some countries. Indonesia is one of the countries in Southeast Asia which is facing "double burden" namely in lowering the
Maternal Mortality Ratio (MMR) and Infant Mortality Rate (IMR). Some provinces in Indonesia which become the focus of a decrease in Neonatal Mortality Rate (NMR) and are known as the Regional Intensive Treatment (WPI) include 12 provinces in Indonesia, one of which is South Sumatra Province. Neonatal Mortality Rate (NMR) for South Sumatra province is 20 per 1,000 live births, which is higher than the national rate (19 per 1,000 live births) (BPS, BKKBN, Kementrian Kesehatan, 2013). Based on Health Profile of Palembang in 2013, it is found that Seberang Ulu I District is the largest contributor to neonatal mortality by the number of neonatal mortality 39 infants (26.9\%). Therefore, the purpose of this study is to identify the determinants of the neonatal death risk in the district of Seberang Ulu I Palembang, South Sumatra Province.

\section{Method}

This research employed a descriptive and analytical approach through case control study design. The populations in this study were divided into two, namely the case and control populations. The case population was all live-born infants who died up to the age of 28 days and the control population was all live-born infants who did not die until the age of 28 days. Control population came from the same population with case population. The samples in this study were also divided into two, namely case samples and control samples based on inclusion and exclusion criteria that had been set by researchers. The inclusion criteria was the same between case and control groups, differing only in status of died or did not die until the maximum age of 28 days. The inclusion criteria included single births, the last child or first child, and willingness of mothers to be respondents. The exclusion criteria in case group was mothers with history of severe diseases (Diabetes Melitus and heart attack), while the exclusion criteria in the control group were died before the baby was born and mothers' houses had been visited twice but the mothers were in the place.

The independent variable included infants/baby factors (gender and birth weight), maternal factor (mother's age at delivery, complications of pregnancy, birth 
Table 1. The Calculation of Minimum Sample Size

\begin{tabular}{|c|c|c|c|c|c|c|c|}
\hline \multirow[t]{2}{*}{ No. } & \multirow[t]{2}{*}{ Variables } & \multirow[t]{2}{*}{ Research (Year) } & \multirow[t]{2}{*}{$\mathrm{P}_{1}$} & \multirow[t]{2}{*}{$\mathrm{P}_{2}$} & \multicolumn{2}{|c|}{$\begin{array}{l}\text { Minimum Number } \\
\text { of Samples }\end{array}$} & \multirow{2}{*}{$\begin{array}{l}\text { Comparison } \\
\text { between Case: } \\
\text { Control }\end{array}$} \\
\hline & & & & & Case & Control & \\
\hline 1. & $\begin{array}{l}\text { Infant with Low } \\
\text { Birth Weight }\end{array}$ & $\begin{array}{l}\text { Prabamurti, et.al } \\
(2008)\end{array}$ & $41,38 \%$ & $10,34 \%$ & 40 & 40 & $1: 1$ \\
\hline 2. & $\begin{array}{l}\text { Complications } \\
\text { of labor }\end{array}$ & $\begin{array}{l}\text { Pongkapadang, } \\
\text { et.al (2014) }\end{array}$ & $57,5 \%$ & $27,6 \%$ & 56 & 56 & $1: 1$ \\
\hline 3. & $\begin{array}{l}\text { Mothers' age } \\
\text { during the birth }\end{array}$ & $\begin{array}{l}\text { Prabamurti, et.al } \\
(2008)\end{array}$ & $55,17 \%$ & $13,79 \%$ & 26 & 26 & $1: 1$ \\
\hline
\end{tabular}

complications, parity and spacing), health services factor (antenatal care, birth attendance, place of birth, type of delivery, immediately breastfeeding and postnatal visits) and sociodemographic factors (maternal education and family welfare).

The sample size in this study was calculated using the formula of independent proportion hypothesis testing 2 groups of two sides.

The minimum sample size was calculated using some research results related to variables in this study. The results obtained are as follows:

Based on the calculation of the minimum sample size, the sizes of samples for cases and controls were calculated in the study. Therefore, this study employed 56 babies as cases group and 56 babies as controls group. However, based on the Health Profile of Palembang in 2013, there were 39 infants experiencing neonatal deaths (cases) so that by using a ratio of $1: 3$, the obtained 39 baby as cases and 117 infants as controls. This was done in order to meet the minimum number of samples which had been obtained from the calculation in Table 1.

Method for data collection was done by collecting primary data through interviews using a questionnaire. Cases of neonatal mortality which were reported to the Department of Health of Palembang through verbal autopsy documents (AV) were traced to the residence to do the interview. Only cases recorded in the Health Department were included in the study. Secondary data was obtained from mother and infant data cohorts (study document) and was available at Seberang Ulu I Health Center District Palembang. The data processing was done through the stages of editing (checking the completeness and correctness of the data that had been collected), coding (a process to provide a code on the data that was to facilitate the processing of data), entry (a process by which data was transferred in a medium for data processing), tabulating (the process by which data were entered in the form of a frequency distribution table).

Data analysis was performed using the techniques of univariate, bivariate and multivariate analysis. The univariate analysis was done to explain/describe the frequency distribution of characteristics of each variable (dependent and independent) in accordance with the type of data. Therefore, a clear picture of data could be obtained (simplifying the collection of data from interviews). The bivariate analysis was conducted to determine the relationship between the two variables. Bivariate test used in this study (hypothesis testing) was Chi-square test and the calculation of the value Odds Ratio (OR) with 95\% Confidence Interval (95\% CI) for analyzing the risk (OR) incidence of neonatal mortality. The final analysis used was the analysis multivariate. In this stage, the analysis of the relationship among all independent and dependent variables was conducted. Multiple regression logistics test was performed to identify the relationship between all independent and dependent variables. Therefore, the final model and the dominant factors on the incidence of neonatal mortality could be obtained. Terms of independent variables that had to be expanded into a multivariable analysis were the variables with $\mathrm{p}<0.25$. There were two steps involved in this multivariate analysis, namely bivariate selection and multiple logistic regression. Before entering the stage of the logistic regression analysis, the selection of independent variables was made. The goal was to eliminate any confounding variables. 
Each independent variable was analyzed using simple logistic regression test. If the analysis produces $\mathrm{p}<0.25$ then these variables could directly enter the multivariable analysis phase. For independent variables with $p \geq 0.25$ but they are substantially important, these variables could be included in the analysis multivariate. The second step was a multivariable modeling. This multivariable modeling used multiple logistic regression. All variables with $\mathrm{p}<0.25$ were included in the model and then one by one, the independent variable with $p>0.05$ were excluded from the model. If the changes of OR value to independent variable was $\geq 10 \%$ when particular independent variable was excluded, those variables had to be included again in the logistic regression model. These steps were carried out continuously to obtain the most parsimonious regression model.

\section{Results and Discussion}

Table 2 shows the proportion of respondents characteristics from various factors which are examined. Infants with male gender have higher proportion of $2 \%$ as compared to the children with female gender. Only about less than $15.0 \%$ of infants are born with low birth weight (LBW). Mothers who are 20-35 years old during the delivery have the largest proportion $(80.0 \%)$. In addition, less than $45.0 \%$ of women experience complications of pregnancy and childbirth. A total of nearly $70.0 \%$ of respondents receive complete antenatal care (once during first trimester, once during first trimester and twive during the third tmester). The proportion of infants who receive breast milk immediately and those who do not is almost evenly. The proportion of the respondents' characteristics by sociodemographic factors shows that as many as $65.4 \%$ of women are educated up to junior high school (Table 2).

Table 3 shows results of bivariate analysis by testing the relationship between the various risk factors for neonatal mortality by using the chi-square test. There is a relationship between various risk factors and neonatal death proven by $p$ value $\leq 0,05$. Based on the value of $p$, it is known that there is a relationship between birth weight $(\mathrm{p}=0.00)$, maternal age at delivery $(\mathrm{p}=0.01)$, Birth spacing $(\mathrm{p}=0.07)$, antenatal care $(\mathrm{p}=0.00)$, immediately breastfeeding $(\mathrm{p}=0.00)$ and postnatal visit $(\mathrm{p}=0.00)$ with neonatal mortality. While gender $(\mathrm{p}=1.00)$, complications of pregnancy $(\mathrm{p}=0.63)$, birth complications $(\mathrm{p}=0.45)$, parity $(\mathrm{p}=0.25)$, birth attendants $(\mathrm{p}=0.57)$, place of birth $(\mathrm{p}=0.68)$, types of delivery $(\mathrm{p}=0.23)$, Mothers' education $(\mathrm{p}=0.69)$ and the welfare of the family $(\mathrm{p}=$ 1.00) are not associated with neonatal mortality.

In this study, the analysis is done until stage of multivariable analysis using multiple logistic regression. The initial step in conducting multiple logistic regression is to make the bivariate selection. Bivariate selection is the stage of selecting candidates of variables which will be included in the multivariable analysis. The variables included in the multivariable analysis are variables with $\mathrm{p}<0.25$ (obtained from the value of Onimbus Tests of Model Coefficients). Based on the bivariate selection results, variables that can be included in the multivariable modeling are birth weight $(\mathrm{p}=$ $0.00)$, mother age at delivery $(\mathrm{p}=0.01)$, parity $(\mathrm{p}=0.18)$, birth spacing $(\mathrm{p}=0.05)$, antenatal care $(\mathrm{p}=0.00)$, birth attendants $(\mathrm{p}=0.19)$, the type of delivery $(\mathrm{p}=0.16)$, breastfeeding (IMD) $(\mathrm{p}=0.00)$, and postnatal visit $(\mathrm{p}=0.00)$.

After the bivariate selection phase is done, the next step is to evaluate the results of multivariate logistic regression. The evaluation was performed based on the value of $\mathrm{z}$ and the value of Wald statistical test. The outcome of variables is done in several stages starting with variable that has the largest $p$-value or the lowest $z$ value. The variables are kept in the model if, after variable outcome, there is changes value $\mathrm{OR} \geq 10 \%$ toward the other variable. The evaluation result can be seen in Table 5 (Model of parsimony End).

Based on Table 4, it shows that the risk of neonatal mortality is not only caused by one factor (single causa), but due to various factors (multiple causa) including birth weight, mother age at delivery, parity, birth spacing, immediately breastfeeding and postnatal visit. One factor of concern is birth weight. Most infants (53.8\%) with low birth weight (LBW) experience neonatal mortality (Table 3). Therefore, mothers who give birth to babies with low birth weight (LBW) has 18.22 times higher risk for experiencing neonatal mortality 
Table 2. Proportion of Determinant Respondents' Characteristics with Neonatal Mortality Risk in Seberang Ulu I District Palembang 2015

\begin{tabular}{|c|c|c|c|}
\hline Variables & Category & Number (n) & Percentage (\%) \\
\hline \multicolumn{4}{|l|}{ Dependent Variables } \\
\hline \multirow[t]{2}{*}{ Neonatal Mortality } & Case group & 39 & $25,00 \%$ \\
\hline & Control Group & 117 & $75,00 \%$ \\
\hline \multicolumn{4}{|l|}{ Infants/Baby Factors } \\
\hline \multirow[t]{2}{*}{ Gender } & Male & 92 & $59,00 \%$ \\
\hline & Female & 64 & $41,00 \%$ \\
\hline \multirow[t]{2}{*}{ Infants birth weight } & LBW (Low Birth Weight) & 133 & $85,30 \%$ \\
\hline & NBW (Normal Birth Weight) & 23 & $14,70 \%$ \\
\hline \multicolumn{4}{|l|}{ Maternal factors } \\
\hline \multirow[t]{2}{*}{ Mother's age at delivery } & 20-35 years old & 122 & $78,20 \%$ \\
\hline & $<20$ and/or $>35$ years old & 34 & $21,80 \%$ \\
\hline \multirow[t]{2}{*}{ Pregnancy complication } & Yes & 57 & $36,50 \%$ \\
\hline & No & 99 & $63,50 \%$ \\
\hline \multirow[t]{2}{*}{ Birth complication } & Yes & 66 & $42,30 \%$ \\
\hline & No & 90 & $57,70 \%$ \\
\hline \multirow[t]{2}{*}{ Parity } & $\leq 2$ Children & 98 & $62,80 \%$ \\
\hline & $>2$ Children & 58 & $37,20 \%$ \\
\hline \multirow[t]{3}{*}{ Birth Spacing } & First Child & 45 & $28,80 \%$ \\
\hline & $<24$ Months & 17 & $10,90 \%$ \\
\hline & $\geq 24$ Months & 94 & $60,30 \%$ \\
\hline \multicolumn{4}{|l|}{ Health Services Factors } \\
\hline \multirow[t]{2}{*}{ Antenatal care } & Not checked and not complete & 48 & $30,80 \%$ \\
\hline & Complete & 108 & $69,20 \%$ \\
\hline \multirow[t]{2}{*}{ Birth attendants } & Health officers & 153 & $98,10 \%$ \\
\hline & Non health officers & 3 & $1,90 \%$ \\
\hline \multirow[t]{2}{*}{ Place of birth } & Medical facility & 149 & $95,50 \%$ \\
\hline & Non-medical facility & 7 & $4,50 \%$ \\
\hline \multirow[t]{2}{*}{ Types of birth } & Normal & 128 & $82,10 \%$ \\
\hline & C-Section & 28 & $17,90 \%$ \\
\hline \multirow[t]{2}{*}{ Immediately breastfeeding } & Yes & 86 & $55,10 \%$ \\
\hline & No & 70 & $44,90 \%$ \\
\hline \multirow[t]{2}{*}{ Postnatal visit } & Yes & 73 & $46,80 \%$ \\
\hline & No & 83 & $53,20 \%$ \\
\hline \multicolumn{4}{|l|}{ Social-Demography Factors } \\
\hline \multirow[t]{2}{*}{ Mother's education } & $\leq \mathrm{SMP}$ & 102 & $65,40 \%$ \\
\hline & $>$ SMP & 54 & $34,60 \%$ \\
\hline \multirow[t]{2}{*}{ Welfare level of family } & Low & 126 & $80,80 \%$ \\
\hline & High & 30 & $19,20 \%$ \\
\hline
\end{tabular}

Source: Primary Data 
Table 3. Determinants of Neonatal Mortality Risks in Seberang Ulu I District Palembang 2015

\begin{tabular}{|c|c|c|c|c|c|c|c|c|}
\hline \multirow{3}{*}{ Variables } & \multirow{3}{*}{ Category } & \multicolumn{4}{|c|}{ Neonatal Mortality } & \multirow{3}{*}{ OR } & \multirow{3}{*}{ OR (95\% CI ) } & \multirow{3}{*}{ p-value } \\
\hline & & \multicolumn{2}{|c|}{ Cases } & \multicolumn{2}{|c|}{ Controls } & & & \\
\hline & & $\mathrm{n}$ & $\%$ & $\mathrm{n}$ & $\%$ & & & \\
\hline \multirow[t]{2}{*}{ Gender } & Male & 23 & 59,0 & 69 & 59,0 & 1,00 & $0,48-2,09$ & $1,00^{* *}$ \\
\hline & Female & 16 & 41,0 & 48 & 41,0 & & & \\
\hline \multirow{2}{*}{$\begin{array}{l}\text { Infants birth } \\
\text { eight }\end{array}$} & LBW & 21 & 53,8 & 2 & 1,7 & 67,08 & $14,48-310,77$ & $0,00^{*}$ \\
\hline & NBW & 18 & 46,2 & 115 & 98,3 & & & \\
\hline \multirow{2}{*}{$\begin{array}{l}\text { Mother's age at } \\
\text { delivery }\end{array}$} & 20-35 years old & 24 & 61,5 & 98 & 91,5 & 0,31 & $0,14-0,69$ & $0,01^{\star}$ \\
\hline & $\begin{array}{l}<20 \text { and/or }>35 \text { years } \\
\text { old }\end{array}$ & 15 & 38,5 & 19 & 16,2 & & & \\
\hline \multirow{2}{*}{$\begin{array}{l}\text { Pregnancy } \\
\text { complication }\end{array}$} & No & 23 & 59,0 & 76 & 65,0 & 0,78 & $0,37-1,63$ & $0,63^{* *}$ \\
\hline & Yes & 16 & 41,0 & 41 & 35,0 & & & \\
\hline \multirow{2}{*}{$\begin{array}{l}\text { Birth } \\
\text { complication }\end{array}$} & No & 20 & 51,3 & 70 & 59,8 & 0,71 & $0,34-1,46$ & $0,45^{\star *}$ \\
\hline & Yes & 19 & 48,7 & 47 & 40,2 & & & \\
\hline \multirow[t]{2}{*}{ Parity } & $\leq 2$ Children & 21 & 53,8 & 77 & 65,8 & 0,61 & $0,29-1,27$ & $0,25^{\star *}$ \\
\hline & $>2$ Children & 18 & 46,2 & 40 & 34,2 & & & \\
\hline \multirow[t]{2}{*}{ Birth spacing } & $<24$ Months & 8 & 26,7 & 9 & 11,1 & 2,91 & $1,00-8,44$ & $0,07^{\star}$ \\
\hline & $\geq 24$ Months & 22 & 73,3 & 72 & 88,9 & & & \\
\hline \multirow[t]{2}{*}{ Antenatal care } & $\begin{array}{l}\text { Not checked and not } \\
\text { complete }\end{array}$ & 20 & 51,3 & 28 & 23,9 & 3,30 & $1,57-7,14$ & $0,00^{*}$ \\
\hline & Complete & 19 & 48,7 & 89 & 76,1 & & & \\
\hline \multirow{2}{*}{$\begin{array}{l}\text { Birth } \\
\text { attendants }\end{array}$} & Health officers & 39 & 100,0 & 114 & 97,4 & - & - & $0,57^{\star *}$ \\
\hline & Non health officers & 0 & 0,0 & 3 & 2,3 & & & \\
\hline \multirow[t]{2}{*}{ Place of birth } & Medical facility & 38 & 97,4 & 111 & 94,9 & 0,49 & $0,06-4,17$ & $0,68^{\star *}$ \\
\hline & Non-medical facility & 1 & 2,6 & 6 & 5,1 & & & \\
\hline \multirow[t]{2}{*}{ Types of birth } & Normal & 29 & 74,4 & 99 & 84,6 & 0,53 & $0,22-1,27$ & $0,23^{* *}$ \\
\hline & C-section & 10 & 25,6 & 18 & 15,4 & & & \\
\hline \multirow{2}{*}{$\begin{array}{l}\text { Immediately } \\
\text { breastfeeding }\end{array}$} & No & 37 & 94,9 & 33 & 28,2 & 47,09 & $10,73-206,61$ & $0,00^{\star}$ \\
\hline & Yes & 2 & 5,1 & 84 & 71,8 & & & \\
\hline \multirow[t]{2}{*}{ Postnatal visit } & No & 31 & 79,5 & 52 & 44,4 & 4,84 & $1,05-11,43$ & $0,00^{*}$ \\
\hline & Yes & 8 & 20,5 & 65 & 55,6 & & & \\
\hline \multirow{2}{*}{$\begin{array}{l}\text { Mothers } \\
\text { education }\end{array}$} & $\leq \mathrm{SMP}$ & 27 & 69,2 & 75 & 64,1 & 1,26 & $0,58-2,74$ & $0,69^{* *}$ \\
\hline & $>\mathrm{SMP}$ & 12 & 30,8 & 42 & 35,9 & & & \\
\hline \multirow{2}{*}{$\begin{array}{l}\text { Welfare level of } \\
\text { family }\end{array}$} & Low & 31 & 79,5 & 95 & 81,2 & 0,89 & $0,36-2,22$ & $1,00^{\star *}$ \\
\hline & High & 8 & 20,5 & 22 & 18,8 & & & \\
\hline
\end{tabular}

Source: Processed Primary Data

*: Sig $\leq 0,05$

$* *$ : Sig $>0.05$

as compared to mothers who give birth to the babies with normal birth weight (NBW) (95\% CI: 1.36 to $243.17, \mathrm{p}=0.03$ ) after being controlled by a factor of mother age, parity, birth spacing, immediately breastfeeding this research are supported by the results of the study Sari (2014) which states that babies born with low birth weight (LBW) have a 4.1 times higher likelihood of neonatal mortality as compared with those born with normal and postnatal visit (Table 4), the results of birth weight (NBW) (95\% CI: 1.8 to 9.4). In 
Table 4. Determinants Modeling of Neonatal Mortality Risk in Seberang Ulu I District Palembang 2015

\begin{tabular}{|c|c|c|c|c|c|}
\hline \multirow{2}{*}{ Variables } & \multirow{2}{*}{ Category } & \multicolumn{2}{|l|}{ Model 1} & \multicolumn{2}{|l|}{ Model 2} \\
\hline & & OR (95\% CI) & $\mathrm{p}$ Value & OR $(95 \%$ CI $)$ & $\mathrm{p}$ Value \\
\hline \multirow{2}{*}{$\begin{array}{l}\text { Infants Birth } \\
\text { Weight }\end{array}$} & LBW & Ref. & - & Ref. & - \\
\hline & NBW & $18,34(1,16-288,63)$ & 0,04 & $18,22(1,36-243,17)$ & 0,03 \\
\hline \multirow{2}{*}{$\begin{array}{l}\text { Mothers' Age at } \\
\text { Delivery }\end{array}$} & 20-35 years old & Ref. & - & Ref. & - \\
\hline & $\begin{array}{l}<20 \text { and/or }>35 \\
\text { years old }\end{array}$ & $1,56(0,21-11,46)$ & 0,66 & $1,55(0,22-11,03)$ & 0,67 \\
\hline \multirow[t]{2}{*}{ Parity } & $\leq 2$ Children & Ref. & - & Ref. & - \\
\hline & $>2$ Children & $1,39(0,33-5,92)$ & 0,66 & $1,42(0,34-5,97)$ & 0,63 \\
\hline \multirow[t]{2}{*}{ Birth Spacing } & $<24$ Months & $3,36(0,52-21,73)$ & 0,20 & $3,16(0,54-18,29)$ & 0,20 \\
\hline & $\geq 24$ Months & Ref. & - & Ref. & - \\
\hline \multirow[t]{2}{*}{ Antenatal Care } & $\begin{array}{l}\text { Not checked and } \\
\text { not complete }\end{array}$ & $1,06(0,22-5,17)$ & 0,94 & - & - \\
\hline & Complete & Ref. & - & - & - \\
\hline \multirow[t]{2}{*}{ Birth Attendants } & Health Officers & - & - & - & - \\
\hline & Non Health Officers & - & - & - & - \\
\hline \multirow[t]{2}{*}{ Types of Birth } & Normal & Ref. & - & - & - \\
\hline & C-section & $0,84(0,12-5,98)$ & 0,86 & - & - \\
\hline \multirow{2}{*}{$\begin{array}{l}\text { Immediately } \\
\text { Breastfeeding }\end{array}$} & No & $37,02(5,81-235,80)$ & 0,00 & $35,95(5,88-219,84)$ & 0,00 \\
\hline & Yes & Ref. & - & Ref. & - \\
\hline \multirow{2}{*}{$\begin{array}{l}\text { Postnatal Care } \\
\text { Visit }\end{array}$} & No & $12,66(2,50-64,07)$ & 0,00 & $13,13(2,67-64,45)$ & 0,00 \\
\hline & Yes & Ref. & - & Ref. & - \\
\hline
\end{tabular}

Source: processed Primary Data

addition, several studies which have been done have proved this, among other are research conducted by Lawoyin et al (2010) in Nigeria which expresses the same finding that infants with low birth weight $(<2500$ grams) have the possibility 4.4 times higher in experiencing neonatal mortality as compared with normal birth weight ( $\geq 2500$ grams) (95\% CI: 2.4 to 8.3 ) and the results of research Nascimento, et al. (2012) in Brazil also shows the same results that there is a relationship between low birth weight (LBW) in neonatal mortality in which babies born weighing <2500 grams have 14.75 times higher of neonatal death as compared with those born weight $\geq 2500$ grams ( $95 \%$ CI: 5.26 to $41.35, \mathrm{p}=0.00$ ).

Infants' birth weight is infants' weight within the first hour after birth, whereas low birth weight babies (LBW) refers to a newborn whose weight at birth is less than 2500 grams. Low birth weight has a tendency toward an increase in the occurrence of infection and susceptible complication. The result of research from Simbolon (2012) states that the probability of neonatal infants survival with low birth weight $(94.65 \%)$ is lower than the probability of survival of neonatal infants with normal weight (98.75\%). The lower the birth weight, the lower the probability of infant survival neonatal. One effort that can be done to minimize the risk of low birth weight (LBW) is through the efforts of kangaroo care method. Some of the benefits of kangaroo care method (PMK) for infants is to increase the growth and development of babies, to add the weight of babies, to help baby sleeping more soundly and longer, to stabilize the baby's heartbeat, to have a better ability in maintaining body temperature, to better breathing (flow oxygen), to make baby more stable psychologically, to make breastfeeding lasts longer and to faster the discharge from the hospital. In addition to the benefits for the baby, the benefits of kangaroo care method is also felt by mothers, among others, to have 
higher compassion toward baby, to reduce stress after birth, symptoms of depression are lower, to give more confident and competent in meeting the needs of infants, to reduce bleeding, to accelerate faster delivery of the placenta and to reduce pain after C-section delivery (Shrivastava et al, 2013).

In addition, immediately breastfeeding factor is the factor that mostly influences neonatal mortality. Almost all (94.9\%) infants who are not breastfed immediately have experienced neonatal mortality (Table 3 ). This proves that breastfeeding is very important to be given immediately to newborn babies so that the risk of neonatal mortality can be reduced. The results of this study also suggest that babies who are not breastfed immediately are at risk for neonatal mortality by 35.95 times higher than those who get immediately breastfeeding ( $95 \%$ CI: 5.88 to $219.84, p=0.00$ ) after being controlled by a factor of birth weight, maternal age, parity, birth spacing and postnatal visit (Table 4). Immediately breastfeeding is one way to prevent neonatal mortality. Research by Edmond (2006) in Ghana reveals that the initiation of early breastfeeding done in the first hour of birth can save $22 \%$ of the infants from the risk of neonatal death. If the first breastfeeding begins on the first day of life then just $16 \%$ of the babies could be saved from the risk of neonatal death. Early breastfeeding delays by more than one day will increase 2.4 times the risk of neonatal death as compared with infants who get early breastfeeding before 24 hours. In line with this, the research conducted by Bamji (2008), in India also shows that early initiation of breastfeeding is significantly associated with neonatal mortality. The research by Garcia (2011) in South India also shows a line that the breastfed infants $>24$ hours after birth have a lower survival in the neonatal period than in breastfed infants within $<12$ hours $(\mathrm{RR}=1.76$; $95 \%$ CI: 1.01 to 3.07$)$. In addition, these results are also consistent with the results of research by Debes (2013) which states that there is a protective relationship between early initiation of breastfeeding with neonatal mortality (within 48 hours after birth) (RR $=0.56$; 95\% CI: 0.40 to 0.79 ). Therefore, it is very important for expectant mothers to get knowledge about the benefits of breastfeeding immediately after birth.

Research from Raharjo (2014) states that there is a relationship between knowledge about the benefits of breastfeeding right away with the practice of giving IMD ( $p=0.001)$ and as many as $52.5 \%$ of women have less knowledge about the IMD. This is because although the mothers have been informed about the IMD by midwives during antenatal examination, but ways of doing IMD is still rarely practiced by midwives. IMD has a very important benefit for infants and mothers. By performing IMD, the failure will be much reduced so the baby's survival is naturally longer. The instinct and reflexes of baby are very strong, so soon after birth the baby is ready to get the main intake of nutrients from breast milk (ASI). In addition to the benefits for the baby, immediately breastfeeding is also beneficial for the mother. Anggorowati's research results (2013) state that a history of breast-feeding effect on the incidence of breast cancer (women who do not breastfeed will have a greater risk for breast cancer). One condition that affects this is the hormonal mechanism. During breastfeeding, the mother produces the hormone prolactin that suppresses exposure to the hormone estrogen in large quantities and in the long term it can trigger breast cancer. Therefore, through the process of breastfeeding, the mother will avoid the risk of breast cancer.

Another factor that influences neonatal mortality is postnatal visit. As many as $79.5 \%$ infants who do not receive postnatal visit (visits by health workers after the baby is born) have neonatal mortality (Table 3 ). The result of this study also shows that babies who do not get a postnatal visit after the birth have 13.13 times higher risk for neonatal mortality than babies who receive postnatal visits after birth (95\% CI: 2.67 to $64.45, p=0.00$ ) after being controlled by a factor of birth weight, maternal age, parity, birth spacing as well as immediately breastfeeding (Table 4). The results are consistent with research by Blencow (2011), stating that the good practice of postnatal care would reduce neonatal mortality. The results of the study by Sari (2014) also shows a line that infants who do not receive postnatal visit (postnatal care) after birth have a 3.16 times higher risk for neonatal mortality than babies who receive postnatal visit (95\% CI: 1.73 
-5.77). Therefore, the postnatal visit is one of the possible interventions in reducing neonatal mortality because the incidence of death in infants and toddlers occur in the neonatal period. Riskesdas 2007 shows that $78.5 \%$ of neonatal mortality occurs at the age of $0-6$ days. Neonatal visit is one of the interventions to reduce newborn mortality through which visits can be identified early neonatal disease or danger signs so that they can receive help immediately to prevent the disease getting worse and death.

Mother age at delivery is one of the confounding variables (confounding factors) in multivariate modeling. Most mothers (78.2\%) are 20-35 years at delivery (Table 2). This shows that most mothers are in childbearing age (safe ages to give birth). Thus, the results of this study show that babies born to mothers aged 20-35 years have 0.31 times lower risk for neonatal mortality than babies born to mothers aged $<20$ or $>35$ years (95\% CI: 0.14 to 0.69 ). The results are consistent with the results of research conducted by Machando (2005) and Kumar (2013) which conclude that the maternal age effects on neonatal mortality. In addition, the results of research conducted by Welaga (2013) concludes that the neonatal mortality occurs more frequently in women less than 20 years old as compared to mothers aged 20-35 years. It is also revealed in Mekonnen (2013) that the neonatal mortality in infants in Ethiopia is more common among 18 years old women. Women who get pregnant at a young age, in terms of the biological development of reproductive organs, are not yet fully optimized. They have not developed psychical immaturity to deal with the moral, mental and emotional burdens. Financially, they are not yet ready to be independent and in terms of medical health, pregnant woman under the age of 20 years old will experience a variety of obstacles that will have an impact on the increased risks of pregnancy. In addition, if a pregnant woman is too old, they also have risks due to the function of the reproductive organs which have suffered a setback toward organ function abnormalities and emergence of degenerative such as hypertension, diabetes mellitus and so forth. Therefore, the risk of death is increased if the mother age is 35 years old or more. The finding is in line with research conducted by Bashir (2013) in Sudan stating that babies with mothers over 40 years old have a greater risk from having neonatal death because the woman who have reached the age of 40 years or more will generally experience fertility declines so it will affect the baby.

Another confounding variable in multivariate modeling is parity. Parity is a state of giving birth both alive and died as well as the status of the pregnancy termination (number of pregnancies that have been experienced by the mother). Based on the results of the study, $53.8 \%$ mothers with parity $\leq 2$ children give birth to babies who experience neonatal mortality (Table 3 ). The result shows that there is no relationship between parity and neonatal mortality $(p=0.25)$. The results are consistent with research from Sari (2014) which states that there is no relationship between parity and neonatal mortality $(\mathrm{p}=0.123)$. However, these results are not consistent with research by Welaga (2013), Machando (2005), Simbolon (2012) which state that there is a significant relationship between parity with the possibility of neonatal mortality. Mothers with first pregnancy have a 1.89 times higher risk for infants in experiencing neonatal mortality as compared to mothers who are not with the first pregnancy (OR $=1.89$ (95\% CI: 1.54 to 2.32 ) (Welaga, 2013).

Birth spacing is also a confounding variable in multivariable modeling. Based on the result, it is obtained information that as many as $26.7 \%$ of babies are born with birth spacing $<24$ months have neonatal deaths (Table 3), with an average age of mothers at delivery is 22 years old and $62.5 \%$ do antenatal care during pregnancy. This shows that there are still many women who are not using antenatal examination during the pregnancy. Besides, the average age of mothers in childbirth are still in younger age groups, so it is important to provide information on the benefits of antenatal care for pregnant mothers and ideal birth spacing for mothers. The study has also shown that infants with birth spacing $<24$ months have a 2.91 times higher risk of neonatal death as compared with infants with birth spacing $\geq 24$ months (95\% CI: 1.00 to 8.44). According to the recommendation issued by the National 
Population and Family Planning (BKKBN), ideal birth spacing is 2 years or more because of short birth spacing would cause mothers not to have enough time to recover hers body after the previous birth. This is one of the causes of weakness and maternal mortality as well as babies born. Risk reproduction process can be suppressed if the minimum distance between the births is two years. Simbolon's research result (2012) shows that there is a relationship between birth spacing with neonatal infant survival probability ( $\mathrm{p}$-value $<0.001$ ). However, the result is different from the results of Mahmudah (2011) which states that there is no relationship between the birth spacing with perinatal mortality $(\mathrm{p}=0.064)$.

The other variables contained in modeling are antenatal care, birth attendants and type of childbirth. Those variables play an important role in the survival of babies in the neonatal period. Based on the results of the study, as many as $76.1 \%$ of women who receive antenatal care in full, their babies do not experience neonatal mortality, with an average age of mothers in childbirth 27 years and $64 \%$ do not experience complications during pregnancy. This suggests that maternal antenatal care is important to be obtained during an oversight of pregnancy. Antenatal care before delivery is mainly aimed at the growth and development of the fetus in the womb. The purposes of antenatal care are to monitor mothers' health care, to early detect the concomitant diseases and complications of pregnancy, to establish the risk of pregnancy so that mothers and babies spared from death, to set up a wellchildbirth and to maintain and prepare infants and lactation. In addition, pregnant women are entitled to health care by skilled professionals during pregnancy to standard antenatal care, namely measuring body weight, measuring blood pressure, measuring height fundus, complete TT immunization, provision of iron tablets at least 90 tablets during pregnancy, tests for STIs, HIV/AIDS and malaria and colloquium (counseling) in preparation for the referral (Depkes RI, 2007). Titaley (2010) states that the antenatal care visits conducted to mother during pregnancy has positive influence on neonatal mortality, as expressed also by Machando (2005) that neonatal mortality is more common among women who do not receive antenatal care regularly.

The results also finds that almost all (98.1\%) of mothers giving birth with the help of health workers (Table 2) with as many as $74.5 \%$ of mothers who gave birth with the help of health professionals, their babies do not experience neonatal mortality. According to the Law of the Republic of Indonesia No. 362014 on health officers, health officers are people who dedicate themselves to the health sector and have knowledge and/or skill through education in the field of health for certain types required by the authority to make health efforts. Health officers have an important role to improve the quality of health care up to the public so that the public is able to raise awareness, willingness and ability of healthy living that will manifest high health standard as an investment for the development of human resources socially and economically. In addition, based on research result, as many as $95.5 \%$ of women deliver at health facilities (Table 2) with $74.5 \%$ of mothers who give birth with the help of health professionals, their babies do not experience neonatal mortality. According to the Law of the Republic of Indonesia No. 362014 on health officers, health-care facilities are tools or places used to organize health care efforts, both as preventive, curative and rehabilitative actions undertaken by the Government, Local Government, and / or community. This shows that awareness is emerging in pregnant women to perform safe delivery with the help of health professionals and in health care facilities.

\section{Conclusion}

Several efforts in preventing neonatal mortality are very important because neonatal mortality is the largest contribution to mortality on babies. The immediately breastfeeding is the most influential factor in preventing neonatal mortality. Therefore, it takes a cross-sectorial cooperation between the BKKBN, the Department of Health and Higher Education to promote the benefits of immediately breastfeeding to pregnant women and to improve the promotion of maternal and child health about the good and safe pregnancy.

\section{References}


Anggorowati, Lindra. 2013. Faktor Risiko Kanker Payudara Wanita. KEMAS, 8 (2) : 121-126.

Bamji, Mahtab S., et al. 2008. Maternal Nutritional Status \& Practices \& Perinatal, Neonatal Mortality in Rural Andhra Pradesh, India. Indian J ournal of Medical Research, 127 : 4451.

Bashir AO, et al. 2013. Neonatal Mortality in Sudan: Analysis of The Sudan Household Survey, 2010. BMC Public Health, 13 (1) : 287.

Blencow, H., et al. 2011. Clean Birth and Postnatal Care Practices to Reduce Neonatal Deaths From Sepsis and Tetanus: A Systematic Review and Delphi Estimation of Mortality Effect. BMC Public Health, 11 (Suppl 3) : S11.

BPS, BKKBN, Kementerian Kesehatan. 2013. Survei Demografi dan Kesehatan Indonesia 2012. Jakarta: BPS, BKKBN, Kementerian Kesehatan.

Debelew, G. T., Afework, M. F. \& Yalew, A. W. 2014. Determinants and Causes of Neonatal Mortality in Jimma Zone, Southwest Ethiopia: A Multilevel Analysis of Prospective Follow Up Study. PLoS One, 9 (9) : e107184.

Debes, Amanda K., Anjalee Kohil, Neff Walker, Karen Edmond, \& Luke C. Mullany. 2013. Time to Initiation of Breastfeeding and Neonatal Mortality and Morbidity: A Systematic Review. BMC Public Health, 13 (Suppl 3):S19.

Depkes RI. 2007. Pedoman Pelayanan Antenatal. Jakarta: Direktorat Bina Pelayanan Medik Dasar.

Edmond, K. M., et al. 2006. Delayed Breastfeeding Initiation Increases Risk of Neonatal Mortality. Pediactrics, 117 (3) : 905.

Garcia, CR et al. 2011. Breast-Feeding Initiation Time and Neonatal Mortality Risk Among Newborns in South India. Journal of Perinatology, 31: 397-403.

Kemenkes RI. 2013. Buletin Jendela Data \& Informasi Kesehatan Volume 2. Jakarta: Kementerian Kesehatan RI.

Kumar, C., Singh, K. P., Rai, K. R. \& Singh, L. 2013. Early Neonatal Mortality in India, 19902006. J Community Health, 38 : 120-130.

Lawoyin T, Onadeko M, Asekun-Olarinmoye E. 2010. Neonatal Mortality and Perinatal Risk Factors in Rural Southwestern Nigeria: A Community-Based Prospective Study. West African Journal of Medicine, 29(1) : 19-23.

Mahmudah et al. 2011. Faktor Ibu dan Bayi yang Berhubungan dengan Kejadian Kematian Perinatal. KEMAS, 7 (1) : 41-50.
Machando, J. C. \& Hill, K. 2005. Maternal, Neonatal and Community Factors Influencing Neonatal Mortality in Brazil. J Biosoc Sci, 37 : 193-208.

Mekonnen, Y. et al. 2013. Neonatal Mortality in Ehiopia: Trends and Determinants. $B M C$ Public Health, 13 : 483.

Mosley, W. H. \& Chen, L. C. 2003. An Analythical Framework for The Study of Child Survival in Developing Countries.Bulletin of the world Health Organization, 81:140-145.

Nascimento RMd, et al. 2012. Determinants of Neonatal Mortality: A Case-Control Study in Fortaleza, Ceará State, Brazil. Cadernos de Saúde Pública, 28(3) : 559-572.

Raharjo, Bambang Budi. 2014. Profil Ibu dan Peran Bidan dalam Praktik Inisiasi Menyusu Dini dan ASI Eksklusif. KEMAS, 10 (1) : 53-63.

Rajaratnam JK, et al. 2010. Neonatal, Postneonatal, Childhood, and Under-5 Mortality for 187 Countries, 1970-2010: A Systematic Analysis of Progress Towards Millennium Development Goal 4. The Lancet, 375 (9730) : 1988-2008.

Sari, Indah Purnama. Berat Badan Lahir Rendah (BBLR) Terhadap Kematian Neonatal. 2014. Prosiding Pertemuan Ilmiah Nasional Kependudukan dan Pembangunan Berkelanjutan. Jakarta: IPADI \& Pusat Kesehatan Reproduksi FK UGM.

Shrivastava SR, Shrivastava PS, Ramasamy J. 2013. Utility of Kangaroo Mother Care in Preterm and Low Birthweight Infants. South African Family Practice, 55(4) : 340-344.

Simbolon, Demsa. 2012. Berat Lahir dan Kelangsungan Hidup Neonatal di Indonesia. Jurnal Kesehatan Masyarakat Nasional, 7(1) : 8-15.

Titaley CR, et al. 2010. Iron and Folic Acid Supplements and Reduced Early Neonatal Deathsin Indonesia. Bulletin of TheWorld Health Organization, 88(7):500-508.

Titaley CR, et al. 2008. Determinants of Neonatal Mortality in Indonesia. BMC Public Health, $8(1): 232$.

Upadhyay, R., et al. 2011. Determinants of Neonatal Mortality in Rural Haryana: A Retrospective Population Based Study. Indian Pediatric, 49(4) : 291-294.

Welaga P, et al. 2013. Why Are Babies Dying in The First Month After Birth? A 7-Year Study of Neonatal Mortality in Northern Ghana. PLoS One, 8 (3) : e58924. 